\title{
PENGGUNAAN GOOGLE CLASSROOM SEBAGAI MEDIA PEMBELAJARAN PADA MATA PELAJARAN BAHASA ARAB DI MAN 3 BOYOLALI
}

\author{
Rubini, Ikhwan Nur Rois \\ STAI Masjid Syuhada Yogyakarta \\ RubiniHr80@gmail.com, roisnur04@gmail.com
}

\begin{abstract}
ملخص
وسائل الإعلام التعليمية هي العنصر الأساسي الداعم في التعلم ، وخاصة الظروف الحالية. الفصول الدراسية بجوجل (google classroom) هي إحدى (ب) الوسائط التي يمكن تطبيقها . كان الغرض من هذه الدراسة هو تحديد كيفية استخدام الفصول الدراسية في جوجل (google classroom). في تعلم اللغة العربية في المدرسة الثانوية الحكومية الإسلامية الثالثة ببويولالي . هذا النوع من البحث النوعي مع المنهج الوصفي . تقنيات جمع البيانات باستخدام الملاحظة والمقابلات والتوثيق. تصف نتائج هذه الدراسة كيفية استخدام الفصول الدراسية (google classroom) كوسيلة تعليمية في المواد العربية في المدرسة الثانوية الحكومية الإسلامية الثالثة ببويولالي. وما هي العقبات التي تعترض عملية التعلم والحلول الواجب تطبيقها. الكلمات المفتاحية : الفصول الدراسية, الوسائل التعليمية للعربية.
\end{abstract}

\begin{abstract}
Learning media is the main supporting element in learning, especially the current conditions. Google classroom is one of the media that can be applied. The purpose of this study was to determine how to use Google classroom in Arabic learning at MAN
\end{abstract}


Rubini, Ikhwan Nur Rois : Penggunaan Google Classroom sebagai Media Pembelajaran pada Mata Pelajaran Bahasa Arab di Man 3 Boyolali

3 Boyolali. This type of research is qualitative with a descriptive approach. Data collection techniques using observation, interviews and documentation. The results of this study describe how the use of google classroom as a learning medium in Arabic subjects in MAN 3 Boyolali and what are the obstacles in the learning process and the solutions to be applied.

Keywords: Google classroom, Learning Media, Arabic

\section{Pendahuluan}

Bahasa Arab merupakan akar dari segala ilmu pengetahuan baik ilmu agama maupun ilmu dunia, sebagaimana yang penulis dapatkan peta konsep di gedung pascasarjana UIN Maulana Malik Ibrahim Malang. Hal tersebut dapat dibuktikan bahwa segala ilmu pengetahuan tersebut terdapat pada sumber-sumber agama Islam seperti Al-Qur'an dan As-Sunnah, selain itu juga dapat kita dijumpai bahwa ilmu-ilmu pengetahuan tersebut dikuasai oleh umat Islam dari zaman sahabat hingga zaman Bani Abbasiyyah, yang mana itu semua tentunya tertulis dengan bahasa Arab. Bahasa Arab merupakan bahasa kedua setelah bahasa ibu, yang mana bahasa Arab dalam pengajarannya bertujuan untuk meningkatkan 3 aspek, yaitu: kognitif, afektif dan psikomotorik pada peserta didik. ${ }^{1}$ Bahasa Arab dalam pembelajarannya sangat bersifat dinamis, hal ini dibuktikan dengan begitu banyak penemuan baru dalam proses pembelajarannya, baik dari segi

1 Thu'aimah, Rusydi Ahmad, Al-Maroji' fii Ta'lim al-Lughoh al-Arobiyyah Li Nathiqiina bilughoti Ukhro. ( Makkah: Ma'had al-Lughoh al-arobiyyah Universitas Ummul Quro, 1986), hlm. 125.

\section{IHTIMAM}


Rubini, Ikhwan Nur Rois : Penggunaan Google Classroom sebagai Media Pembelajaran pada Mata Pelajaran Bahasa Arab di Man 3 Boyolali

pendekatan hingga model pembelajaran serta tak menutut kemudian juga yaitu segi media pembelajarannya, semakin bertambahnya zaman maka semua akan mengikuti sehingga muncul penemuan yang baru ataupun terinovasi guna mempermudah mengajari bahasa Arab tersebut.

Pembelajaran bahasa Arab memiliki lima rukun pembelajaran, diantaranya: pendekatan pembelajaran, metode pembelajaran, tehnik pembelajaran, model pembelajaran dan media pembelajaran. Kelima rukun tersebut akan mencapai tujuan pembelajaran tertentu, yang mana kelima rukun itu bersifat saling menguatkan dan melengkapi dalam proses pembelajaran. Tujuan pembelajaran yang dirancang tergantung pada penggunaan sebuah media pembelajaran, karena media dengan tujuan pembelajaran memiliki kesesuaian dalam proses pembelajaran (Afiffah, 2020: 317). ${ }^{2}$ Bahasa Arab di Indonesia telah dipelajari dari tingkat sekolah dasar atau madrasah ibtidaiyyah hingga sekolah menengah atas atau madrasah Aliyah, sebagai contoh tingkat madrasah Aliyah..

Madrasah Aliyah Negeri 3 Boyolali atau dikenal dengan MAN 3 Boyolali memiliki dua jurusan, yaitu: MIPA (Matematika IPA), dan Ilmu Pengetahuan Sosial (IPS) yang mana bahasa Arab dipelajari pada setiap jurusan tersebut akan tetapi berbeda materimateri yang dipelajari. Penulis mengambil jurusan MIPA dan IPS

2 Prananingrum, A. V., Rois, I. N., \& Sholikhah, Anna, Kajian Teoritis Media Pembelajaran Bahasa Arab, Dalam Prosiding Konferensi Nasional Bahasa Arab VI, Malang: Sastra Arab Universitas Negeri Malang, 2020. 
Rubini, Ikhwan Nur Rois : Penggunaan Google Classroom sebagai Media Pembelajaran pada Mata Pelajaran Bahasa Arab di Man 3 Boyolali

kelas $\mathrm{X}$ (sepuluh) yang mana pada kedua jurusan tersebut dipelajari mata pelajaran bahasa Arab. Era new normal saat ini menuntut setiap elemen pendidikan menerapkan pembelajarannya secara daring (online), salah satunya di MAN 3 Boyolali. Peneliti mengamati sejak awal kalender pendidikan semester gasal ini telah menerapkan pembelajaran di sekolah dengan tatap muka maupun daring, maka dari itu peneliti melihat salah satu media yang digunakan ketika menerapkan pembelajaran secara daring, oleh karena itu media pembelajaran sangat menjadi garda terdepan pada dunia pendidikan daring ini. Hal ini dibuktikan bahwa pembelajaran bahasa Arab di kelas X baik jurusan MIPA ataupun IPS tersebut menggunakan sebuah aplikasi teknologi yaitu Google classroom.

Google classroom merupakan suatu aplikasi teknologi berbasis website yang dimanfaatkan sebagai salah satu media pembelajaran. Google classroom dapat digunakan baik melalui smartphone maupun sistem desktop, selain itu google classroom dapat menerima segala format file baik Microsoft word, Microsoft excel, Power point, zip, dan lain sebagainya maupun berupa teks, gambar, video, audio bahkan link-link tertentu. Aplikasi google classroom ini telah digunakan oleh guru bahasa Arab sebagai media pembelajaran di sekolah tersebut. Berdasarkan latar belakang yang telah penulis sampaikan diatas, maka rumusan masalah dalam penelitian ini adalah bagaimana penggunaan aplikasi google classroom sebagai media pembelajaran pada mata pelajaran bahasa

\section{4}


Rubini, Ikhwan Nur Rois : Penggunaan Google Classroom sebagai Media Pembelajaran pada Mata Pelajaran Bahasa Arab di Man 3 Boyolali

Arab di MAN 3 Boyolali dan apa saja hambatan-hambatan dalam proses pembelajarannya serta solusi yang akan diterapkan. Adapun tujuan dari penelitian ini adalah untuk mendeskripsikan penggunaan aplikasi google classroom tersebut dalam proses pembelajaran bahasa Arab peminatan dan mengetahui hambatanhambatannya serta memberikan solusi kedepannya.

\section{Media Pembelajaran}

Pada poin landasan teori artikel ini, penulis mengambil teori menurut media pembelajaran adalah segala sesuatu yang dapat dilihat dan berfungsi sebagai alat perantara dalam proses pembelajaran dengan tujuan dapat merangsang pikiran, perasaan, dan kemauan siswa. ${ }^{3}$ Nana Sudjana dan Ahmad Rivai media pembelajaran berperan sebagai alat bantu guna menciptakan proses pembelajaran secara efektif, yang mana alat bantu tersebut dapat mudah memahami materi kepada siswa, alat bantu juga bersifat audio visual yaitu dapat dilihat dan didengar. ${ }^{4}$ Menurut Seels dan Glasgow dalam Azhar Arsyad membagi media pembelajaran menjadi dua kelompok, yaitu: ${ }^{5}$ tradisional dan mutakhir. Media pembelajaran tradisional berupa 1) Visual diam yang diproyeksikan seperti: filmstrips, slides, apaque dan overhead, 2)

${ }^{3}$ Khalilullah. M, Media Pembelajaran Bahasa Arab, (Yogyakarta: Aswaja Pressindo, 2012), hlm. 24

4 Sudjana \& Ahmad Rivai, Media Pengajaran, (Bandung: Sinar Baru, 1991), hlm. 99

5 Azhar Arsyad, Media Pembelajaran, (Jakarta: Raja Grafindo Persada, 2011), hlm. 33 
Rubini, Ikhwan Nur Rois : Penggunaan Google Classroom sebagai Media Pembelajaran pada Mata Pelajaran Bahasa Arab di Man 3 Boyolali

Visual diam seperti: gambar, poster, foto, grafik, diagram, dan lainnya, 3) Audio seperti: pita kaset, rekaman piringan, reel dan lainya, 4) Penyajian multimedia seperti: tape, 5) Visual dinamis seperti: film, televisi, video, 6) Media cetak seperti: buku, majalah ilmiah, workbook, dan lainnya, 7) Permainan seperti: teka-teki, stimulasi dan permainan papan dan 8) Media realita seperti: model, specimen dan peta boneka. Adapun media pembelajaran mutakhir berupa 1) Media berbasis telekomunikasi seperti: teleconference, kuliah atau belajar jarak jauh, 2) Media berbasis mikroprosesor seperti: computer-assisted instruction, permainan komputer, sistem tutor intelijen.

\section{Media Pembelajaran Bahasa Arab}

Kata media merupakan bentuk jama' (banyak) yang artinya alat perantara-perantara dan bersifat umum. Adapun bentuk mufrad (satu) berasal dari kata medium, kata tersebut diambil Kamus Besar Ilmu Pengetahuan (dalam Dagun, 2006: 634) media merupakan perantara/ penghubung yang terletak antara dua pihak. Adapun pembelajaran diartikan dengan suatu proses transfer ilmu dari seorang guru kepada siswanya guna mencapai tujuan pembelajaran tertentu, sehingga Media pembelajaran adalah sebuah alat perantara yang digunakan dalam kegiatan proses pembelajaran guna mencapai tujuan pembelajaran.

Media pembelajaran dalam bahasa Arab memiliki beberapa istilah diantaranya al-Wasa'il al-Idhah, al-Wasa'il al-Ta'liim, al-Wasa'il 
Rubini, Ikhwan Nur Rois : Penggunaan Google Classroom sebagai Media Pembelajaran pada Mata Pelajaran Bahasa Arab di Man 3 Boyolali

al-Ta'limiyah atau al-Mu'ayyanaat al-Sam'iyah wa al-Bashariyah, Khalilullah (2012: 23). Pembelajaran bahasa Arab memiliki fokus empat keterampilan bahasa (al-Maharoh al-Lughoh) yaitu maharah istima', maharah kalam, maharah qiro'ah dan maharah kitabah. Sehingga media pembelajaran bahasa Arab dapat kami definisikan sebagai alat bantu yang digunakan dalam proses pembelajaran bahasa Arab guna memudahkan dalam memahami materi keempat keterampilan bahasa tersebut. Media pembelajaran saat ini menjadi wajah pembelajaran, hal ini dapat dibuktikan dengan anjuran dari pemerintah terkait kebijakan belajar-mengajar yang dilakukan di rumah masing-masing sejak awal tahun ajaran semester gasal ini dan meningkatnya penggunaan media pembelajaran, baik berbasis aplikasi smartphone maupun desktop.

Media pembelajaran bahasa Arab yang ingin digunakan hendaknya memperhatikan standar pemilihannya, diantaranya: menyesuaikan jenis media dengan materi pelajaran, dapat terjangkau, ketersediaan perangkat keras untuk pemanfaatan media pembelajaran, ketersediaan media pembelajaran di pasaran dan kemudahan dalam memanfaatkannya. Oleh karena itu media pembelajaran bahasa Arab yang digunakan untuk kelas X di MAN 3 Boyolali sudah menyesuaikan dengan standar pemilihan tersebut dan juga situasi serta kondisi proses pembelajaran saat ini. 
Rubini, Ikhwan Nur Rois : Penggunaan Google Classroom sebagai Media

Pembelajaran pada Mata Pelajaran Bahasa Arab di Man 3 Boyolali

\section{Pembelajaran Bahasa Arab di Madrasah Aliyah}

Bahasa Arab merupakan salah satu mata pelajaran yang wajib di MAN 3 Boyolali, dalam pembagian materi pelajaran bahasa Arab setiap jurusannya akan berbeda. Bahasa Arab untuk jurusan MIPA dan IPS biasa dikenal dengan nama bahasa Arab wajib, yang mana materi-materi yang dipelajari dimulai dari hal yang termudah hingga hal yang tersulit dalam mempelajari bahasa Arab. Pembelajaran bahasa Arab memiliki orientasi utama untuk dipelajari yaitu orientasi keagamaan, yang mana orientasi tersebut bertujuan agar pembelajar bahasa Arab dapat memahami isi kandungan Al-Qur'an dan As-Sunnah.

Oleh karena itu bahasa Arab menjadi hal yang penting untuk dipelajari sebagaimana yang dikatakan oleh Umar bin Khattab Semoga Allah meridhoinya dalam (Rois, 2020: 22) yang artinya: Pelajarilah bahasa Arab sesungguhnya ia adalah bagian dari agama kalian. Al-Qur'an dan As-Sunnah kita telah mengetahui ditulis dengan bahasa Arab, untuk memahami itu maka diperlukannya belajar bahasa Arab terkhusus Kaidah-kaidah nahwu, shorof maupun balaghah. Bahasa Arab ini dimulai dengan kelas X sampai kelas XII dengan materi dasar ilmu-ilmu nahwu dan shorof. Adapun tujuan pembelajaran bahasa Arab peminatan untuk kelas X, diantaranya: 1) Mampu mengeskpresikan perasaan, pikiran dan gagasan secara verbal-komunikatif, 2) Mampu menginternalisasi keterampilan berbahasa Arab dengan baik sehingga peserta didik menjadi terampil menggunakan Bahasa

\section{8}


Rubini, Ikhwan Nur Rois : Penggunaan Google Classroom sebagai Media Pembelajaran pada Mata Pelajaran Bahasa Arab di Man 3 Boyolali

Arab dalam berbagai situasi, 3) Mampu menggunakan Bahasa Arab untuk mempelajari ilmu-ilmu agama, pengetahuan umum dan kebudayaan, 4) Mampu mengintegrasikan kemampuan berbahasa Arab dengan perilaku yang tercermin dalam sikap toleran, berpikir kritis dan sistematis (KMA 183 tahun 2019).

\section{Google Classroom sebagai Media Pembelajaran}

Google classroom merupakan salah satu aplikasi berbasis smartphone dan juga berbasis web yang telah banyak penggunanya, bahkan setiap manusia yang memiliki akun email berupa g-mail dapat langsung menggunakannya, hal ini dibuktikan dalam biodata aplikasi google classroom pada playstore bahwasanya lebih dari 100 juta yang telah mengunduhnya, terhitung sejak dirilis tanggal 12 Agustus 2014 hingga saat ini. Google classroom dapat didownload melalui aplikasi smartphone ataupun berbasis desktop, adapun google classroom memiliki beberapa kelebihan bagi para pengguna, diantaranya: 1) Google classroom sebagai media pembelajaran berbasis sistem menejemen atau yang dikenal dengan Learning Management System (LMS), 2) Proses setting pembuatan kelas yang cepat dan nyaman, 3) Hemat dan efisien waktu, 4) Mampu meningkatkan kerjasama dan komunikasi, 5) Penyimpanan data yang terpusat, 6) Berbagi sumber daya yang efisien, praktis dan cepat, 7) Dapat diakses melalui smartphone dan desktop secara bersamaan. 
Rubini, Ikhwan Nur Rois : Penggunaan Google Classroom sebagai Media Pembelajaran pada Mata Pelajaran Bahasa Arab di Man 3 Boyolali

Google classroom memiliki fitur-fitur yang berbeda dengan aplikasi ataupun media teknologi lainnya, diantara fitur google classroom yaitu: 1) Assignments atau tugas, yang mana fitur ini digunakan sebagai wadah setiap tugas yang diberikan guru untuk para siswa, 2) Grading atau penilaian, yang mana fitur ini untuk memantau tugas yang telah dikerjakan oleh para siswa dan guru dapat memberikan komentar langsung terhadap tugasnya, 3) Chatting atau pesan, fitur ini juga tersedia guna berdiskusi secara langsung antara guru dan para siswa, 4) Laporan Orisinilitas, fitur ini digunakan oleh para guru dan siswa untuk mengetahui terkait keaslian tugas yang dikirimkan, 5) Arsip Pembelajaran, fitur inilah yang menjaga dokumen, file dan lainnya selama pembelajaran berlangsung, yang mana arsip ini dapat terkoneksi dengan google drive, 6) Aplikasi Seluler, adapun fitur ini khusus para pengguna google classroom berbasis android, yang mana digunakan untuk melampirkan foto, file yang terdapat pada seluler pengguna, 7) Keamanan Pribadi, fitur ini berfungsi memberikan keamanan kepada para pengguna dari segala bentuk iklan maupun pencurian dokumennya.

Google classroom ini merupakan salah satu media pembelajaran yang diterapkan oleh guru bahasa Arab kelas $X$ di MAN 3 Boyolali. Google classroom ini digunakan karena memiliki layanan yang bagus dan baik sehingga diharapkan terciptanya pembelajaran bahasa Arab yang efektif di saat ini, yang mana dengan aplikasi ini dapat tersampainya materi-materi bahasa Arab 
Rubini, Ikhwan Nur Rois : Penggunaan Google Classroom sebagai Media Pembelajaran pada Mata Pelajaran Bahasa Arab di Man 3 Boyolali

kepada siswa dengan mudah dan fleksibel baik berupa materi maharah istima', kalam, qiro'ah dan kitabah. Oleh karena itu, guru bahasa Arab memilih media pembelajaran menggunakan google classroom. Tak hanya google classroom yang digunakan tentunya ada beberapa layanan aplikasi yang mendukung juga digunakan seperti: whatsapp, google form dan lainnya.

Google Classroom merupakan sebuah produk bagian dari Google For Education yang sangat istimewa, karena produk yang satu ini memiliki banyak fasilitas didalamnya seperti memberi pengumuman atau tugas, mengumpulkan tugas dan melihat siapa saja yang sudah mengumpulkan tugas. Pada situs Google Classroom juga tertulis bahwa Google Classroom terhubung dengan semua layanan Google For Education yang lainnya, sehingga pendidik dapat memanfaatkan Google Mail, Google Drive, Google Calender, Google Dogs, Google Sheets, Google Slide, dan Google Sites dalam proses pembelajarannya. Sehingga saat pendidk menggunakan Google Classroom pendidik juga dapat menggunakan Google Calender untuk mengingatkan peserta didik tentang jadwal atau tugas yang ada, sedangkan penggunaan Google Drive sebagai tepat untuk menyimpan keperluan pembelajaran seperti Power Point, file yang perlu digunakan dalam pembelajaran maupun yang lainnya.

Dengan demikian Google Classroom dapat membantu memudahkan pendidika dan peserta didik dalam melaksanakan kegiatan belajar mengajar dengan lebih mendalam. Hal ini disebabkan karena baik peserta didik atau pendidik dapat 
Rubini, Ikhwan Nur Rois : Penggunaan Google Classroom sebagai Media Pembelajaran pada Mata Pelajaran Bahasa Arab di Man 3 Boyolali

mengumpulkan tugas, mendistribusikan tugas, dan berdiskusi tentang pelajaran dimanapun tanpa terikat batas waktu atau jam pelajaran. Hal tersebut membuat proses pembelajaran lebih menarik dan lebih efisien dalam pengelolaan waktu, dan tidak ada alasan lagi peserta didik lupa tentang tugas yang sudah diberikan oleh pendidik.

Penerapan Media Pembelajaran Bahasa Arab Peminatan melalui Aplikasi Google Classroom

Setelah mengetahui makna dan hakikat media pembelajaran beserta aplikasi google classroom, berikut penerapan media pembelajaran yang digunakan guru bahasa Arab kelas X MAN 3 Boyolali. Pada penerapan ini, peneliti akan membagi menjadi tiga langkah, yaitu: Pertama: tahap persiapan, kedua: tahap pelaksanaan, ketiga: tahap penutupan.

\section{Pertama: Tahap Persiapan}

Tahap persiapan ini, guru hendaknya menyiapkan materi dan tujuan pembelajaran pada pertemuan tersebut, dalam tulisan ini peneliti akan berikan contoh pada materi pengenalan bahasa Arab dasar dan taqsim kalimah. Adapun tahap persiapan yang dilakukan oleh siswa ialah hendaknya memperhatikan segala arahan guru dan dapat hadir tepat waktu. 
Rubini, Ikhwan Nur Rois : Penggunaan Google Classroom sebagai Media Pembelajaran pada Mata Pelajaran Bahasa Arab di Man 3 Boyolali

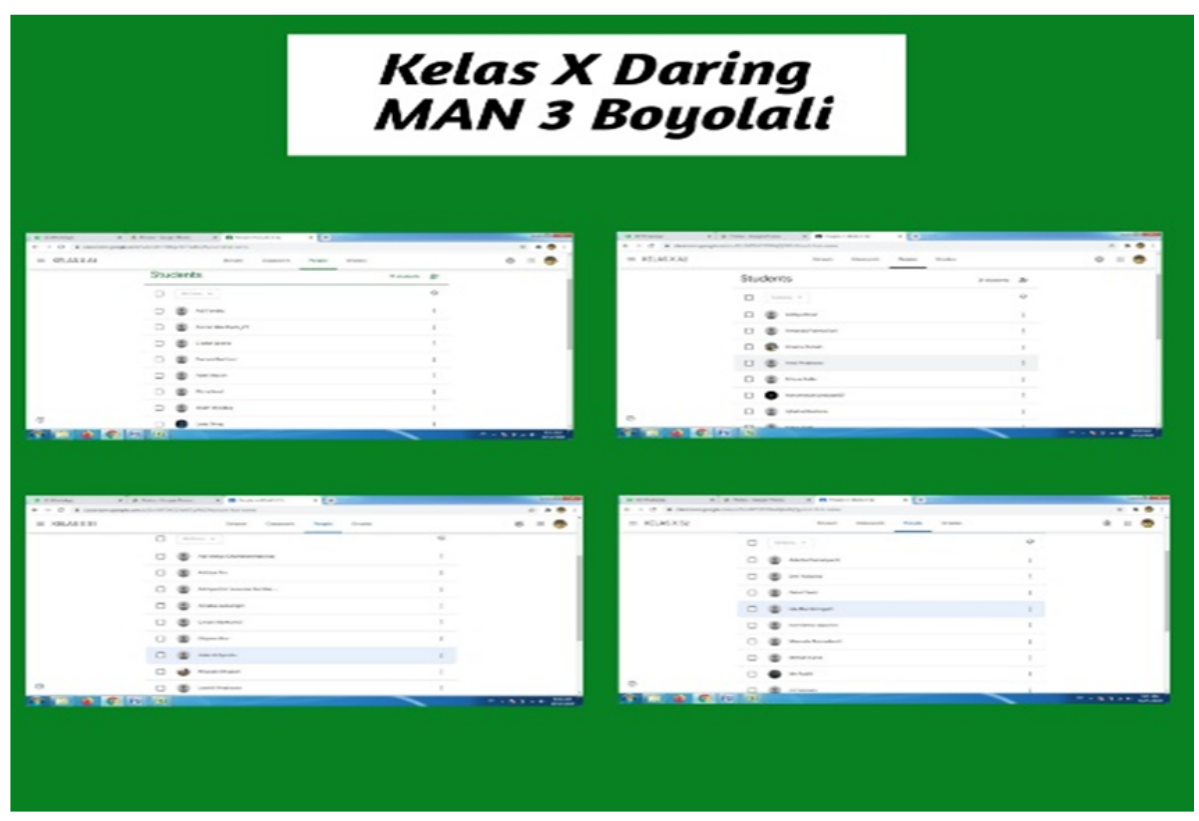

Gambar 1. Data Siswa Kelas X

\section{Kedua: Tahap Pelaksanaan}

Tahap pelaksanaan ini, guru membagikan materi kepada siswa dan menjelaskan melalui sebuah file berupa teks, video maupun evaluasi materi yang telah di upload pada google classroom, kemudian siswa diminta untuk menyimak dengan seksama materi tersebut. Materi pelajaran tersebut di upload dengan tujuan agar para siswa dapat memudahkan untuk mengulangi materi di lain waktu. Adapun untuk bentuk materinya pada google classroom sebagai berikut: 
Rubini, Ikhwan Nur Rois : Penggunaan Google Classroom sebagai Media Pembelajaran pada Mata Pelajaran Bahasa Arab di Man 3 Boyolali

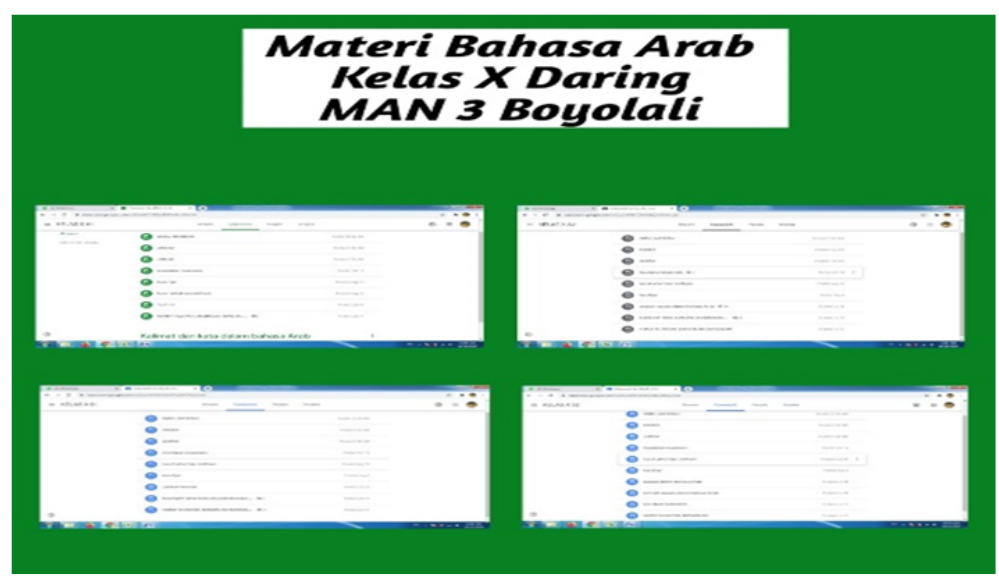

Gambar 3. Materi Bahasa Arab Kelas X

\section{Ketiga: Tahap Penutupan}

Tahap penutupan ini, guru juga membagikan bentuk evaluasi pembelajaran. Hal ini bertujuan untuk mengetahui tingkat pemahaman materi yang telah diajarkan pada pertemuan tersebut, yang mana bentuk evaluasi ini berupa tugas mandiri yang dikerjakan melalui layanan google form, Gunawan (26 Oktober 2020).

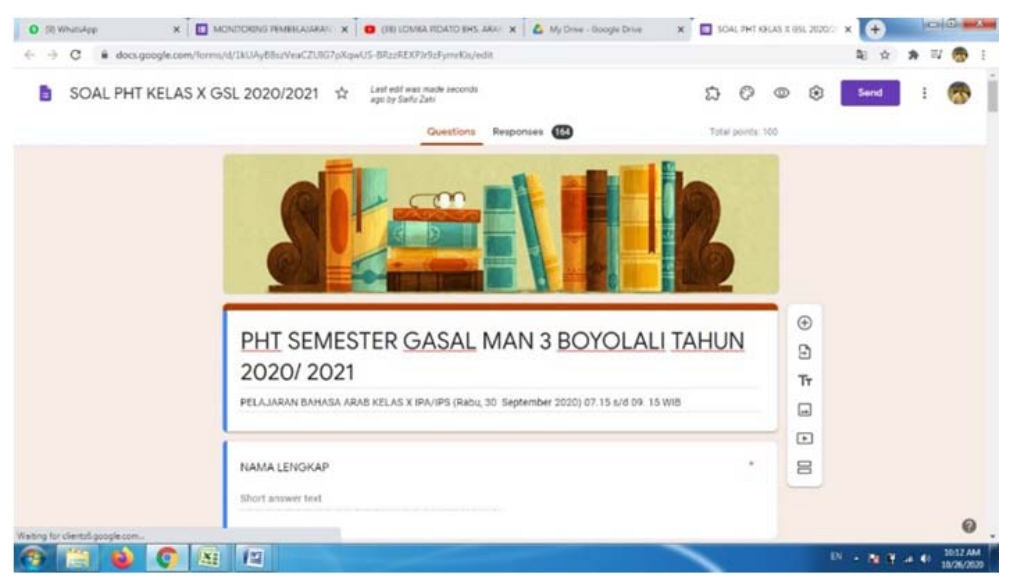

Gambar 4. Evaluasi Materi Bahasa Arab 
Rubini, Ikhwan Nur Rois : Penggunaan Google Classroom sebagai Media Pembelajaran pada Mata Pelajaran Bahasa Arab di Man 3 Boyolali

Penerapan aplikasi google classroom ini pada pembelajaran bahasa Arab tentunya memiliki kelebihan dan kekurangan. Berdasarkan hasil wawancara guru bahasa Arab dengan peneliti, Gunawan (22 Oktober 2020) mengatakan bahwa diantara kelebihannya adalah 1) Dapat mengatasi penyebaran virus covid-19 kepada para siswa, 2) Menjalani proses pembelajaran lebih fleksibel, 3) Materi dapat dipelajari pada lain waktu. Diantara kekurangannya atau hambatan adalah 1) Terkendala sinyal atau jaringan internet siswa, 2) Ketersediaan media pembelajaran siswa berupa handphone maupun laptop, 3) Siswa merasa kurang banyak dalam jam pelajaran, 4) Materi yang disampaikan kurang maksimal, 5) Keaktifan siswa sangat rendah, 6) Kejenuhan siswa dalam belajar online, 7) Kesehatan mata yang terganggu dengan banyaknya radiasi oleh handphone maupun laptop. Hambatan itu yang menjadi masalah yang cukup serius dalam pembelajaran bahasa Arab yang dirasakan, tak hanya bahasa Arab akan tetapi mata pelajaran yang lainnya juga merasakan hambatan yang sama.

Berdasarkan hambatan yang ada, sebuah solusi sangat diperlukan guna meminimalisir hambatan-hambatan lainnya yang kemungkinan terjadi dalam proses pembelajaran. Adapun solusi yang telah dilakukan oleh guru bahasa Arab maupun pihak madrasah ialah memberikan bantuan berupa kuota belajar diawal pembelajaran, memberikan motivasi internal dan eksternal kepada siswa agar tetap semangat menjalani proses pembelajaran, memberikan solusi agar akun google classroom terkoneksi dengan 
Rubini, Ikhwan Nur Rois : Penggunaan Google Classroom sebagai Media

Pembelajaran pada Mata Pelajaran Bahasa Arab di Man 3 Boyolali

handphone. Bagi siswa yang memiliki hambatan berupa tidak adanya handphone dan laptop, maka guru memberikan kesempatan untuk datang ke sekolah dalam satu pekan sekali guna mengikuti pembelajaran yang sudah tersampaikan.

\section{Kesimpulan}

Berdasarkan pembahasan di atas, maka dapat disimpulkan bahwa penerapan aplikasi google classroom sebagai media pembelajaran bahasa Arab peminatan di MAN 3 Boyolali sudah sangat sesuai dengan kondisi saat ini, di lain sisi juga harus bisa lebih memperhatikan media pembelajaran google classroom secara maksimal. Media pembelajaran dalam pemilihannya juga dapat menyesuaikan dengan materi yang akan disampaikan agar para siswa mudah memahami dan mengikuti pembelajaran dengan asyik, terkhusus mata pelajaran bahasa Arab. Setelah dipaparkan terkait penerapan media pembelajaran bahasa Arab melalui aplikasi google classroom di atas, maka diharapkan artikel ini dapat memberikan solusi yang baik bagi pengajar bahasa Arab di Indonesia dan dapat menjadi referensi atau rujukan tulisan untuk penelitian selanjutnya yang terkait topik pembahasan yang relevan. 
Rubini, Ikhwan Nur Rois : Penggunaan Google Classroom sebagai Media Pembelajaran pada Mata Pelajaran Bahasa Arab di Man 3 Boyolali

\section{Daftar Pustaka}

Arsyad, Azhar, Media Pembelajaran. Jakarta: Raja Grafindo Persada, 2011

Dagun, S. M, Kamus Besar Ilmu Pengetahuan. Jakarta: Lembaga Pengakajian Kebudayaan Nusantara (LPKN), 2006

https://google classroom.org/

Keputusan Menteri Agama (KMA) Nomor 183 Tahun 2019, Tentang "Kurikulum Pendidikan Agama Islam (PAI) dan Bahasa Arab".

Khalilullah, M, Media Pembelajaran Bahasa Arab, Yogyakarta: Aswaja Pressindo, 2012

Miles, B. M., \& Huberman, Amichael, Analisis Data Kualitatif Buku Sumber tentang Metode-Metode Baru (Tjetjep Rohendi Rohisi, Penerjemah.). Jakarta: Universitas Indonesia, 2007.

Prananingrum, A. V., Rois, I. N., \& Sholikhah, Anna, "Kajian Teoritis Media Pembelajaran Bahasa Arab", Dalam Prosiding Konferensi Nasional Bahasa Arab VI. Malang: Sastra Arab Universitas Negeri Malang, 2020

Rois, I. N, Al-Qowaidul An-Nahwiyyah Li Mubtadi'in Ma'a I'robiha: Kaidah Nahwu beserta I'robnya untuk Pemula, Yogyakarta: KBM Indonesia, 2002

Serba Serbi, Technology. 2020. Mengenal Apa Itu Google Classroom: Fitur, Fungsi dan Keunggulannya. Diterbitkan melelui link https://idcloudhost.com/mengenal-apa-itugoogle-classroom-fitur-fungsi-dan-keunggulannya/

Diakses pada tanggal 20 Oktober 2020.

Sudjana, Nana dan Ahmad Rivai, Media Pengajaran, Bandung: Sinar Baru, 1991 
Rubini, Ikhwan Nur Rois : Penggunaan Google Classroom sebagai Media

Pembelajaran pada Mata Pelajaran Bahasa Arab di Man 3 Boyolali

Sugiyono, Metode Penelitian Pendidikan: Pendekatan Kuantitatif, Kualitatif, dan R\&D. Bandung: Alfabeta, 2018

Thu'aimah, Rusydi Ahmad, "Al-Maroji' fii Ta'lim al-Lughoh alArobiyyah Li Nathiqiina bilughoti Ukhro, Makkah: Ma'had alLughoh al-arobiyyah Universitas Ummul Quro, 1986 